\title{
Transmission electron microscopic investigation of the dark and light pancreatic acinar beta- -cells of young-domesticated pig (Sus Suidae, Erxleben 1777)
}

\author{
M. Elghoul', R. Kandyle'2, K. Morsy ${ }^{3,4}$, M.M.A. Abumandour ${ }^{5}$ (i) \\ ${ }^{1}$ Department of Histology and Cytology, Faculty of Veterinary Medicine, Alexandria University, Alexandria, Egypt \\ ${ }^{2} Z$ oology Department, Faculty of Science, Tanta University, Tanta, Egypt \\ ${ }^{3}$ Biology Department, Faculty of Science, King Khalid University, Abha, Saudi Arabia \\ ${ }^{4}$ Zoology Department, Faculty of Science, Cairo University, Cairo, Egypt \\ ${ }^{5}$ Department of Anatomy and Embryology, Faculty of Veterinary Medicine, Alexandria University, Alexandria, Egypt
}

[Received: 23 August 2021; Accepted: 29 September 2021; Early publication date: 7 October 2021]

Background: The current study was designed to perform a transmission electron microscopic investigation focusing on the dark and light pancreatic acinar $\beta$-cells of young domesticated pig (Sus Suidae).

Materials and methods: This study depended on the fresh pancreatic specimens from 5 healthy young (2-month-old) pigs that were collected immediately after they were slaughtered at the abattoir of Abdelkader Alexandria, Egypt.

Results and Conclusions: In our findings, the acinar pancreas was formed of pyramidal pancreatic acinar cells with large spherical nuclei of condensed heterochromatin at the periphery and prominent eccentric nucleoli. Zymogen granules were observed at the apical region of the acinar cells, and they appear as electron dense bodies. Numerous mitochondria and Golgi complexes observed in the acinar cell cytoplasm. The electron dense acinar cells were joined by junctional complexes. The rough endoplasmic reticulum was more prominent in the electron-dense acinar cells than did electron-lucent acinar cells. There was no connective tissue capsule separate the acinar portion of pancreas from the pancreatic islets. The pancreatic islets mainly formed of $\beta$-cells. The irregular $\alpha$-cells possess numerous small granules. The cytoplasmic $\beta$-cells granules were surrounded by hallow area and enclosed by a limiting membrane. Delta cells were generally polygonal in shape and found in clumps throughout the islet and they were also identified in between $\beta$-cells. Their granules were of moderate electron density and were generally smaller than $\beta$-cells' granules. The limiting membrane was tightly enclosed the delta cells granules and the hallow area around the granule were found similar to the granules of $\beta$-cells. (Folia Morphol 2022; 81, 4: 956-962)

Key words: pancreas, Sus Suidae, transmission electron microscope, pancreatic islets, pancreatic cells 


\section{INTRODUCTION}

The omnivorous domesticated pig (Sus Suidae, Erxleben 1777) species belong to order Artiodactyla, family Suidae, and genus Sus. These omnivorous domesticated pigs are bred mostly for meat consumption and they feed on plants and sometimes on insects and fish [24].

Pancreas is described anatomically as an accessory portion of the digestive system and from a clinical perspective; it is the starting point for two important diseases, diabetes and pancreatic cancer. It is to be trusted that a superior comprehension of the morphology and histology of this organ will in the long run add to the improvement of novel treatments for either or both of the above conditions [32]. The pancreas is a composite organ comprising exocrine and endocrine parts. The exocrine part consists of acini that discharge digestive enzymes into the pancreatic duct. The endocrine part, the pancreatic islets of Langerhans, is composed of masses of endocrine cells inserted inside the exocrine pancreas. Islet cells secrete pancreatic hormones, such as insulin, glucagon, somatostatin, and pancreatic polypeptide (PP), which circulate throughout the body by means of blood vessels [9].

The pancreas consists of exocrine acini that produce digestive enzymes and endocrine islets that produce hormones. The exocrine acini of the pancreas consist mainly of tubuloacinar glands [10]. The digestive enzymes of the secretory acini are delivered to the intestine through a branched network of ducts. Cells in the endocrine islets produce hormones that regulate the body metabolism via the blood circulation [16]. The endocrine portion of the pancreas is composed of cellular aggregations that are scattered among the pancreatic acini known as islets of Langerhans [12]. The endocrine part of the pancreas represents $1 \%$ or $2 \%$ of the pancreatic mass [19]. The mammalian endocrine pancreas is composed of alpha cells ( $\alpha$-cells or glucagon-producing cells), beta cells ( $\beta$-cells, insulin-producing cells), delta cells ( $\Delta$-cells, somatostatin-producing cells), and F-cells (PP-cells, pancreatic polypeptide-producing cells) as described by Gartner [12].

The available data on the structure of the pancreas generally focus on the histological features of the pancreas in the adult stage. In addition, there is a lack of available data on the structure of the pancreas in newborn animals, especially on the domesticated pig. Therefore, the current work describes the light and electron microscopic structure of the exocrine and endocrine pancreas of the newborn domesticated pig (Sus Suidae). Finally, our findings presented in this study, together with those presented in the previous study, provide a comprehensive report of the microscopic and ultrastructural structure of the pancreas of newly born pig.

\section{MATERIALS AND METHODS}

\section{Sample's collection}

Fresh specimens of pancreases from 5 apparently healthy 2-month-old domesticated pigs (Sus Suidae) were collected immediately after they were slaughtered at the abattoir of Abdelkader Alexandria, Egypt. The young, domesticated pigs (Sus Suidae) were slaughtered for human food, and consequently had been examined prior to slaughter by the slaughterhouse veterinarian to obtain approval for consumption by human. The present investigation was prepared according to the guidelines for the use and care of laboratory animals and followed animal ethics and welfare in the Faculty of Veterinary Medicine, Alexandria University and according to the Egyptian laws.

\section{Transmission electron microscopy (TEM) description}

Fresh pancreatic tissue samples of $1 \mathrm{~mm}$ thickness were obtained, fixed at $4^{\circ} \mathrm{C}$ in a solution of $2.5 \%$ glutaraldehyde for $24 \mathrm{~h}$, rinsed in $0.1 \mathrm{M}$ cacodylate buffer at $\mathrm{pH} 7.4$, then post-fixed for $1 \mathrm{~h}$ at room temperature with $1 \%$ osmium tetroxide. Then, these samples were put at $4^{\circ} \mathrm{C}$ in washing solution formed from $0.1 \mathrm{M}$ sodium cacodylate containing $5 \%$ sucrose, processed by the tannic acid. Samples were dehydrated with ethyl alcohol in a graded sequence and eventually embedded in epoxy resin [17]. For tissue examination, semithin sections were cut and stained with toluidine blue. Ultrathin sections $(50-60 \mu \mathrm{m})$ were cut and stained with uranyl acetate dihydrate and lead citrate saturated solution [20]. Finally, the sections were photographed by JEOL JEM-2100 TEM at Faculty of Science, Alexandria University, Egypt.

\section{RESULTS}

The acinar pancreas was formed from pyramidal pancreatic acinar cells which had relatively large spherical nuclei with condensed heterochromatin at the periphery and prominent nucleoli that were found eccentric to the nucleus (Fig. 1). The cytoplasm con- 


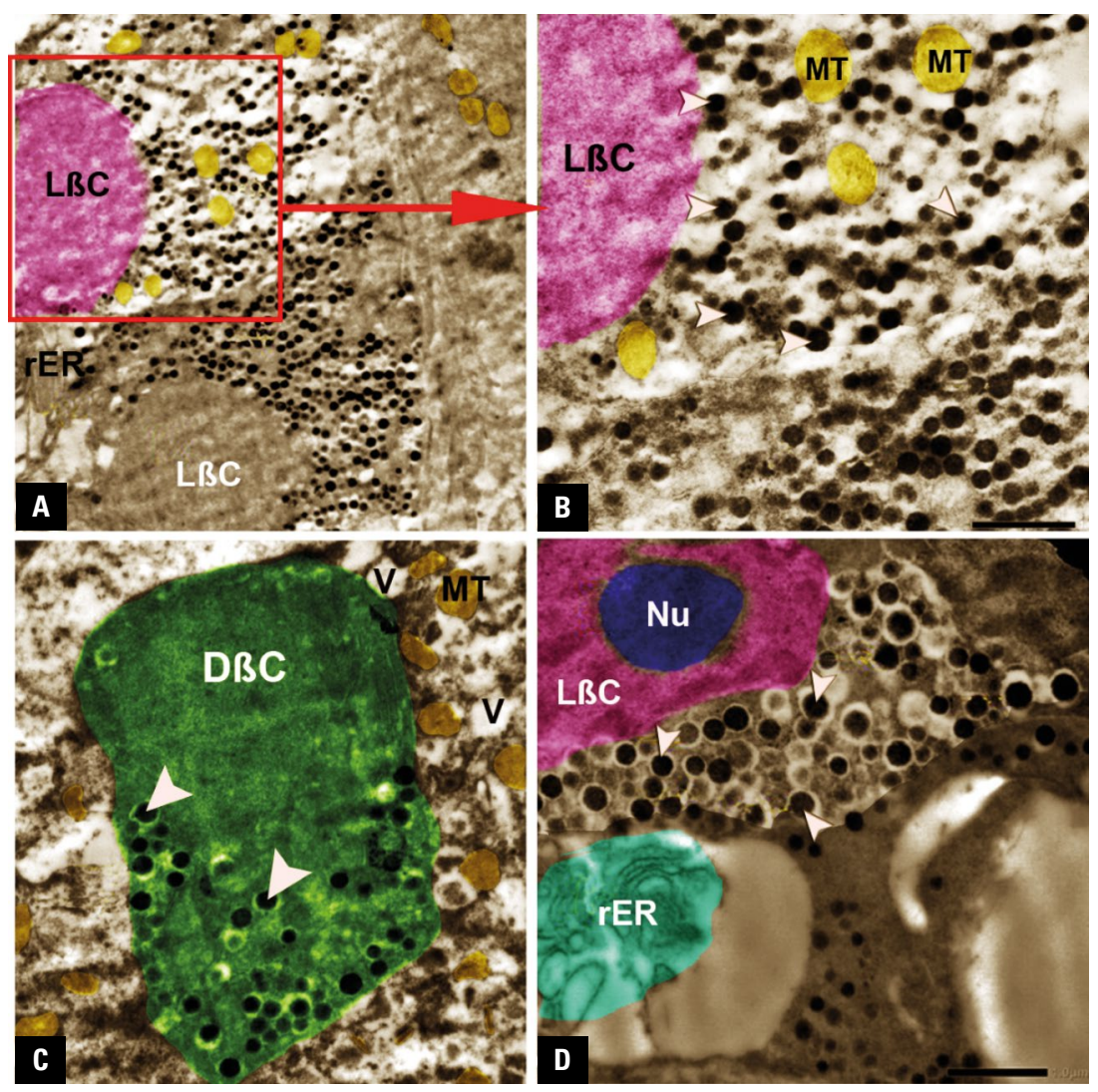

Figure 1. A-D. Transmission electron micrographs of young-domesticated pig's (Sus Suidae) pancreas showing light (L $\beta C$ ) and dark $\beta$-cells $(\mathrm{D} \beta C)$ with slightly oval nuclei, abundant zymogen secretory granules of variable sizes (white arrowheads), numerous mitochondria (MT), rough endoplasmic reticulum (rER), and few vacuoles $(V) ; A: \times 2500 ; B: \times 4000 ; C, D: \times 6000$.

tained cisternae of the rough endoplasmic reticulum (Fig. 1/rER). Zymogen granules were found at the apical region of the acinar cells, and they appeared as electron dense bodies (Fig. 1/white arrowheads). Numerous mitochondria and Golgi complexes were found in the cytoplasm of each acinar cell. The acinar lumen was continuous with the intercalated duct (Fig. 1B/MT). There were two types of acinar cells; the first cellular type was the electron lucent acinar cells characterised by few zymogen granules, and the second cellular type was the electron dense acinar cells characterised by the presence of numerous zymogen granules and electron dense nucleus (Fig. 2/D $\beta C, L \beta C$ ). The electron dense acinar cells were joined by junctional complexes (Fig. 2/star). The centro-acinar cells had centrally located nucleus (Fig. $2 / D \beta C$ and $L \beta C$ ).

The rough endoplasmic reticulum was more prominent in the electron-dense acinar cells than in electron-lucent acinar cells (Fig. 2B-D/rER). There was no connective tissue capsule separating the acinar portion of pancreas from the pancreatic islets. The distribution of pancreatic islets was not uniform, but they were scattered and had different electron density of granules. The pancreatic islets were mainly composed of $\beta$-cells (Fig. 1/L $\beta C, D \beta C$ ). The $\alpha$-cells were characterised by an irregular outline and possessed numerous small granules that were characterised by a moderate to high density and were surrounded by a membrane. The nuclei of the cells were ovoid. Cytoplasmic vacuoles were found and the rough endoplasmic reticulum that consisted of narrow tubules (Figs. 1, 2/rER). The Golgi apparatus appeared as small irregular lamina and their cytoplasmic granules were spherical and were larger than those of $\alpha$-cells. The cytoplasmic $\beta$-cell granules were surrounded by hallow area and enclosed by a limiting membrane (Fig. 2). Delta cells were generally polygonal in shape and found in clumps throughout the islet and they were also identified in between $\beta$-cells (Fig. 2). Their granules were of moderate electron density and were generally smaller than $\beta$-cells' granules. The limiting membrane tightly enclosed the $\Delta$-cells granules and the hallow areas around the granules were found similar to those of the granules of $\beta$-cells. 


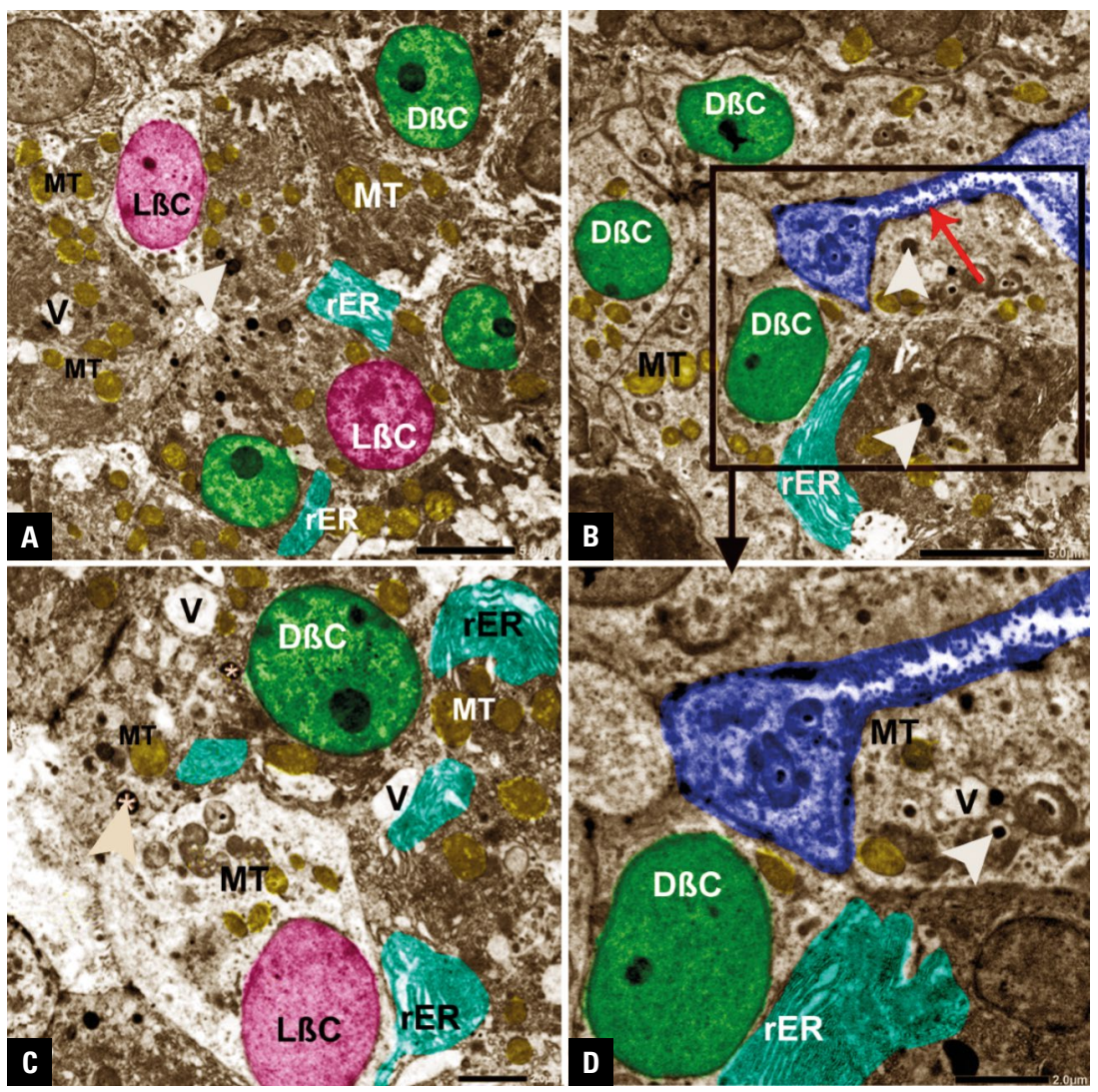

Figure 2. A-D. Transmission electron micrographs of pancreatic acinar gland cells of young-domesticated pig (Sus Suidae) showing the junction between the light $(\mathrm{L} \beta C$ ) and dark $\beta$-cells $(\mathrm{D} \beta C)$ at the microvillus surface (red arrow). Note the presence of zymogen granules (white arrowheads), numerous mitochondria (MT), rough endoplasmic reticulum (rER), and cytoplasmic vacuoles (V) in the cytoplasm of both light and dark $\beta$-cells; $\times 2000$.

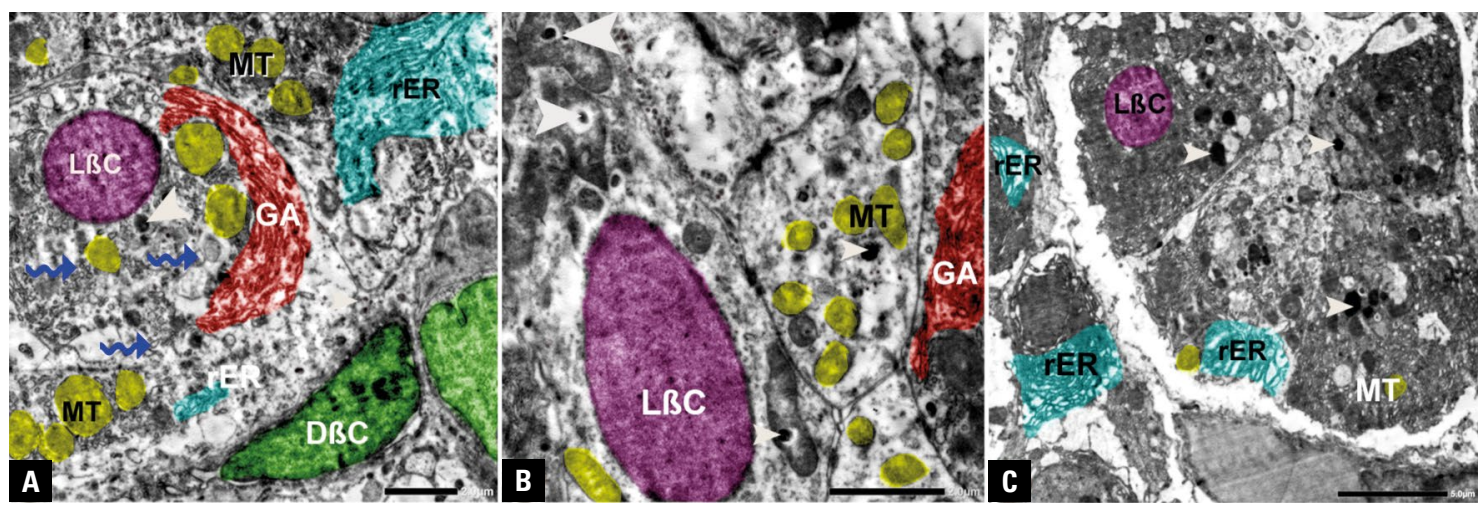

Figure 3. Transmission electron micrograph of pancreatic acinar $\beta$-cells of young domesticated pig's (Sus Suidae) pancreas; light (L $\beta C$ ) and dark $\beta$-cells $(\mathrm{D} \beta C)$. Note the abundant mitochondria (MT), rough endoplasmic reticulum (rER), a well-developed Golgi apparatus (GA), zymogen granules (white arrowheads), and several variable sized vesicles (zigzag arrows).

\section{DISCUSSION}

The small clusters of pancreatic endocrine cells were first depicted by Paul Langerhans in 1869, after whom they were named as "Islets of Langerhans". From that point forward, numerous morphological examinations have been completed utilising the dif- ferent histological and ultrastructural techniques in numerous animal species such as camel $[3,15,21]$, bovine [2, 14], feline [31], monkey [35], rabbit [34], rodent, canines and Guinea pig [11], mice [1], and rat $[6,13,23]$. The endocrine pancreas has likewise been studied in-non mammalian species such as some 
avian species [28, 29], teleost fish [22], lizard [7], and frog [8].

The acinar pancreas is formed of pancreatic acinar cells which have relatively large spherical nuclei with condensed heterochromatin at the periphery and prominent nucleoli located eccentrically within the nucleus. The shape of the acinar cells has some variation as to which the current work reported the pyramidal cells, similar to that reported by Iniyah et al. [18] in large white Yorkshire pigs (Sus Scrofa) and Conklin [5] in Egyptian one-humped camel Camelus dromedarius, while Gupta et al. [14] described some variation of acinar cell shape from columnar to pyramidal in buffalo.

The current ultrastructural observations reported that the zymogen granules appeared as electron dense bodies, similar to that reported by Goldsmith et al. [13]. Zymogen granules were reported also by Gupta et al. [14] in buffalo, Hafez and Zaghloul [15] in Egyptian one-humped camel Camelus dromedarius and Conclin [5] in human pancreas of foetus and by Laitio et al. [26] in foetus at 12 weeks. Moreover, the current work reported that numerous mitochondria and Golgi complexes were found in the cytoplasm of each acinar cell. In addition, acinar lumen was continuous with the intercalated duct, similar to that described by Caro and Palade [4], Gupta et al. [14], Hafez and Zaghloul [15].

There are minor variations about the position of the zymogen granules in acinar cells. The current observations reported that the Zymogen granules were found at the apical region of the acinar cells, similar to that reported by Iniyah et al. [18] in large white Yorkshire pigs (Sus Scrofa) and Hafez and Zaghloul [15] in Egyptian one-humped camel Camelus dromedarius and confirmed in the different animal species by Eurell and Frappier [9] in a text book, while Gupta et al. [14] reported that the zymogenic granules were observed in the supranuclear cellular part of the cell in buffalo.

The current ultrastructural observations reported that there were two types of acinar cells; the first cellular type was the electron lucent acinar cells characterised by few zymogen granules, and the second cellular type was the electron dense acinar cells characterised by the presence of numerous zymogen granules and electron dense nucleus. The current ultrastructural observations reported that the electron dense acinar cells were joined by junctional complexes, in addition to the centro-acinar cells have centrally located nucleus, similar to that reported by Hafez and Zaghloul [15] in Egyptian one-humped camel Camelus dromedarius and Bonner-Weir and Like [2] in Holstein cattle pancreas.

Our ultrastructural study showed the rough endoplasmic reticulum was more prominent in the electron-dense acinar cells than in electron-lucent acinar cells; similar findings were reported by Hafez and Zaghloul [15] in Egyptian one-humped camel Camelus dromedarius. We found no connective tissue capsule separating the acinar portion of the pancreas from the pancreatic islets. The distribution of pancreatic islets was not uniform, but they were scattered and had different electron density of granules.

There are three significant cell types in the islets of Langerhans: $\alpha$-cell producing glucagon, $\beta$-cell producing insulin, and $\delta$-cell producing somatostatin; an arrangement dependent on the pioneer works of Lacy [25] and Munger et al. [30]. Other cell types ( $C, E, F, V$, and $\mathrm{X}$ or $\mathrm{PP})$ that secrete pancreatic polypeptides were seldom seen in a couple of animal species such as camel [15], canine, Guinea pig, rabbit [32] and mice [1]. The current work described the presence of mainly three well-defined cells in the pancreatic islets and the islets mainly consisted of $\beta$-cells; similar observations were made by Bsoul et al. [3] and Khatim et al. [21] in a single hump camel (Camelus dromedarius). The cytoplasmic $\beta$-cells granules were surrounded by hallow area and enclosed by a limiting membrane, similar to that reported by Hafez and Zaghloul [15] in Egyptian one-humped camel Camelus dromedarius.

The current ultrastructural observations reported that the $\alpha$-cells were characterised by an irregular outline and possessed numerous small granules of a moderate to high density surrounded by a membrane. The nuclei of the cells were ovoid. Cytoplasmic vacuoles were found and the rough endoplasmic reticulum that consisted of narrow tubules. The Golgi apparatus appeared as small irregular lamina and their cytoplasmic granules were spherical and were larger than those of $\alpha$-cells. These findings were similar to that reported by Hafez and Zaghloul [15] in Egyptian one-humped camel Camelus dromedarius. Also, Bsoul et al. [3] confirmed these findings in a single hump camel (Camelus dromedarius) but there was a difference consisting in that presence of the spherical nuclei of the polyhedral shaped cells.

Delta cells were generally polygonal in shape and found in clumps throughout the islet and they were 
also identified in between $\beta$-cells. Their secretory granules were of moderate electron density and were generally smaller than $\beta$-cells' granules. The limiting membrane tightly enclosed the $\Delta$-cells granules and the hallow areas around the granules were found similar to those of the granules of $\beta$-cells, which was consisted with the observations reported by Bsoul et al. [3] in a single hump camel (Camelus dromedarius). These findings were similar to that reported by Hafez and Zaghloul [15] in Egyptian one-humped camel Camelus dromedarius but different in that there was no hallow area around the granules. The presence of the $\Delta$-cells was also described in the endocrine part of the pancreas of numerous animal species such as cats [27], rats $[6,13,23]$, and camels $[14,15,21]$.

\section{CONCLUSIONS}

The acinar pancreas was formed of pyramidal pancreatic acinar cells with large spherical nuclei. Electron dense zymogen granules were observed at the apical region of the acinar cells. There was no connective tissue capsule separate the acinar portion of pancreas from the pancreatic islets. The pancreatic islets mainly formed of $\beta$-cells. The irregular $\alpha$-cells possess numerous small granules. The cytoplasmic $\beta$-cells granules were surrounded by hallow area and enclosed by a limiting membrane. Delta cells were generally polygonal in shape and found in clumps throughout the islet and they were also identified in between $\beta$-cells. Their granules were of moderate electron density and were generally smaller than $\beta$-cells' granules. The limiting membrane was tightly enclosed the delta cells granules and the hallow area around the granule were found similar to the granules of $\beta$-cells.

\section{Acknowledgements}

The authors extend their appreciation to the Deanship of Scientific Research at King Khalid University for funding this work through Research Group Project under Grant number (R.G.P.2/40/40).

\section{Conflict of interest: None declared}

\section{REFERENCES}

1. Al-Ani I. Histochemical and ultrastructural studies on the islets of langerhans of lean and obese hyperglycaemic mice with age. Aston University, 1978.

2. Bonner-Weir S, Like AA. A dual population of islets of Langerhans in bovine pancreas. Cell Tissue Res. 1980;
206(1): 157-170, doi: 10.1007/BF00233616, indexed in Pubmed: 6986987.

3. Bsoul M, Salahuddin J, Imad M, et al. Ultrastructure of pancreatic endocrine cells of the single hump camel (Camelus dromedarius). Ann Microscopy. 2013; 13: 36-42.

4. Caro LG, Palade GE. Protein synthesis, storage, and discharge in the pancreatic exocrine cell. An autoradiographic study. J Cell Biol. 1964; 20: 473-495, doi: 10.1083/ jcb.20.3.473, indexed in Pubmed: 14128049.

5. Conklin JL. Cytogenesis of the human fetal pancreas. Am J Anat. 1962; 111: 181-193, doi: 10.1002/aja.1001110204, indexed in Pubmed: 13880851.

6. Elayat AA, el-Naggar MM, Tahir M. An immunocytochemical and morphometric study of the rat pancreatic islets. J Anat. 1995; 186 (Pt 3): 629-637, indexed in Pubmed: 7559135.

7. Epple A. Islet cytology in urodele amphibians. Gen Comp Endocrinol. 1966; 7(2): 207-214, doi: 10.1016/00166480(66)90041-4.

8. Etayo JC, Montuenga LM, Sesma P, et al. Characterization of pancreatic endocrine cells of the European common frog Rana temporaria. Gen Comp Endocrinol. 2000; 117(3): 366-380, doi: 10.1006/gcen.2000.7427, indexed in Pubmed: 10764548.

9. Eurell JA, Frappier BL. Dellmann's textbook of veterinary histology. John Wiley and Sons 2013.

10. Frappier B. Digestive System. In: Eurell J, Frappier B (eds). Dellmann's Textbook of Veterinary Histology, 6th ed. Wiley-Blackwell 2007.

11. Fujita T. The cells and hormones of the GEP endocrine system. The current of studies. Gastro-entero-pancreatic endocrine system. Martinus Nijhoff Publishing 1973: 1-16.

12. Gartner L. Digestive System: Glands. In: Color Textbook of Histology, 3rd ed. Saunders Elsevier, Philadelphia, PA 2006.

13. Goldsmith PC, Rose JC, Arimura A, et al. Ultrastructural localization of somatostatin in pancreatic islets of the rat. Endocrinology. 1975; 97(4): 1061-1064, doi: 10.1210/ endo-97-4-1061, indexed in Pubmed: 1104349.

14. Gupta D, Uppal V, Bansal N, et al. Light and electron microscopic studies on prenatal differentiation of exocrine pancreas in buffalo. Vet Med Int. 2016; 2016: 2414769, doi: 10.1155/2016/2414769, indexed in Pubmed: 26981314.

15. Hafez S, Zaghloul D. Light and electron microscopy of the pancreas of the Egyptian one-humped camel (Camelus dromedarius). Eur J Anat. 2017; 21(1): 37-45.

16. Hafez SA, Zaghloul D, Caceci T. Immunohistochemical identification of the endocrine cells in the pancreatic islets of the camel, horse and cattle. Eur J Anat. 2015; 19(1): 27-35.

17. Hayat M. Basic Techniques for Transmission Electron Microscopy. 2nd edn. Academic Press, Baltimore 1986.

18. Iniyah K, Javachitra S, Arulmozhi A, et al. Histomorphology of exocrine pancreas of large white Yorkshire pigs (Sus scrofa). J Entomol Zool Studies. 2020; 8(3): 1484-1486.

19. Johnston C, Bodansky H, Cudworth A. et al.. Anatomy and Physiology of Pancreatic Islets. In: Besser G (eds). Clinical Diabetes. An Illustrated text. Gower Medical Publishing, London 1988: 1.1-1.14.

20. Kandyel RM, Elwan MM, Abumandour MMA, et al. Comparative ultrastructural-functional characterizations of the 
skin in three reptile species; Chalcides ocellatus, Uromastyx aegyptia aegyptia, and Psammophis schokari aegyptia (FORSKAL, 1775): Adaptive strategies to their habitat. Microsc Res Tech. 2021; 84(9): 2104-2118, doi: 10.1002/ jemt.23766, indexed in Pubmed: 33852761.

21. Khatim MS, Gumaa KA, Petersson B, et al. The structure and hormone content of the endocrine pancreas of the one-humped camel (Camelus dromedarius). Anat Anz. 1985; 159(1-5): 181-186, indexed in Pubmed: 2869718.

22. Klein C, Van Noorden S. Pancreatic polypeptide (PP)- and glucagon cells in the pancreatic islet of Xiphophorus helleri H. (Telecostei). Correlative immunohistochemistry and electron microscopy. Cell Tissue Res. 1980; 205(2): 187-198, doi: 10.1007/BF00234679, indexed in Pubmed: 6986984.

23. Kocamis H, Sari EK, Nazli M, et al. Immunohistochemical distribution of Insulin-, glucagon-, and somatostatin-containing cells in the pancreas of the rat (Wistar albino). Kafkas Univ Vet Fak Derg. 2009; 15: 611-614, doi: 10.9775/ kvfd.2009.086-a.

24. Kongsted AG, Horsted K, Hermansen JE. Free-range pigs foraging on Jerusalem artichokes (Helianthus tuberosus L.): Effect of feeding strategy on growth, feed conversion and animal behaviour. Acta Agriculturae Scandinavica, Section A, Animal Science. 2013; 63(2): 76-83, doi: 10. 1080/09064702.2013.787116.

25. Lacy PE. Electron microscopic identification of different cell types in the islets of Langerhans of the guinea pig, rat, rabbit and dog. Anat Rec. 1957; 128(2): 255-267, doi: 10.1002/ ar.1091280209, indexed in Pubmed: 13458840.

26. Laitio M, Lev R, Orlic D. The developing human fetal pancreas: an ultrastructural and histochemical study with special reference to exocrine cells. J Anat. 1974; 117(Pt 3): 619-634, indexed in Pubmed: 4418855.
27. Legg PG. The fine structure and innervation of the beta and delta cells in the islet of Langerhans of the cat. Z Zellforsch Mikrosk Anat. 1967; 80(3): 307-321, doi: 10.1007/ BF00339324, indexed in Pubmed: 4878690.

28. McClish RD, Eglitis JA. Distribution of the A and B Cells and of the Islets (Langerhans) in the Duck Pancreas. Biology. 1969.

29. Mikami SI, Ono K. Glucagon deficiency induced by extirpation of alpha islets of the fowl pancreas. Endocrinology. 1962; 71: 464-473, doi: 10.1210/endo-71-3-464, indexed in Pubmed: 14473676.

30. Munger BL, Caramia F, Lacy PE, et al. The ultrastructural basis for the identification of cell types in the pancreatic islets. I. Guinea pig. ZZellforsch Mikrosk Anat. 1965; 67(4): 533-546, doi: 10.1007/BF00342585, indexed in Pubmed: 4161302.

31. Sato T, Herman L, Fitzgerald P. The comparative ultrastructure of the pancreatic islet of Langerhans. Gen Comp Endocrinol. 1966; 7(1): 132-157, doi: 10.1016/00166480(66)90094-3.

32. Seymour PA, Bennett WR, Slack JMW. Fission of pancreatic islets during postnatal growth of the mouse. J Anat. 2004; 204(2): 103-116, doi: 10.1111/j.14697580.2004.00265.x, indexed in Pubmed: 15032917.

33. Volk BW, Wellmen KF. The diabetic pancreas. Baillière Tindall, London 1977

34. Williamson JR, Lacy PE, Taylor KW. Appendix: Electron miscroscopy of islets Of langerhans in rabbit pancreas slices incubated in vitro. Biochem J. 1967; 102(3): 928-928.2, doi: 10.1042/bj1020928, indexed in Pubmed: 16742512.

35. Winborn WB. Light and electron microscopy of the islets of langerhans of the saimiri monkey pancreas. Anat Rec. 1963; 147: 65-93, doi: 10.1002/ar.1091470107, indexed in Pubmed: 14062367. 